\title{
The Influence of Strategic Alliance on Competitive Advantage through Market Area and Product Innovation
}

\author{
Taufik Setyadi ${ }^{1}$, Hening Widi Oetomo ${ }^{1}$, Khuzaini $^{1} \&$ Suwitho $^{1}$ \\ ${ }^{1}$ Doctoral Program of Management, Sekolah Tinggi Ilmu Ekonomi Indonesia (STIESIA) Surabaya, Indonesia \\ Correspondence: Taufik Setyadi, Doctoral Program of Management, Sekolah Tinggi Ilmu Ekonomi Indonesia \\ (STIESIA) Surabaya, Indonesia. Tel: 62-31-594-7505.
}

Received: October 30, 2017

Accepted: November 7, 2017

Online Published: November 13, 2017

doi:10.5430/ijba.v8n7p57

URL: https://doi.org/10.5430/ijba.v8n7p57

\begin{abstract}
This study is aimed to prove the implementation of strategic alliance can increasing competitive advantage of wood industry of Perhutani through develop of market area and market innovation. Based on the results of hypothesis testing and the analysis of strategic alliances, market area and product innovation against competitive advantage, it is known that building a competitive advantage in the timber industry forestry can be achieved through the establishment of strategic alliances right, based on the exchange of raw material resources, technology or resources marketing. Strategic alliances are used to strengthen the position of the timber industry in the face of competition forestry business. The more precise the model selection strategic alliance Perhutani timber industry will be able to build competitive advantage of her. The development model of strategic alliances Perhutani timber industry that needs to be developed is to increase the competitive advantage has the form of an alliance focused on cooperation in provision of raw materials, interest in improving the skills of cooperation and the application of the production process technology
\end{abstract}

Keywords: strategic alliance, competitive advantage, market area, product innovation

\section{Introduction}

Indonesia as the largest country in ASEAN with a population of more than 250 million should be able to compete in the market of the ASEAN Economic Community (AEC), so Indonesia must increase the competitiveness of the industry to dominate the market in ASEAN.

ASEAN countries have agreed to make the forestry sector as a motor of economic development. S ector forestry with the furniture industry is a labor-intensive industry. There are at least 4 million people rely on the industry as a source of income.The furniture industry is able to contribute foreign exchange earnings from exports of US \$1.779 billion in 2013, amounting to 50\% of Indonesia's timber and wood product exports. Indonesia's furniture industry also has a very high local content, so that the furniture and handicraft industry is one of the 10 priority export products that can be relied upon to spur the economic growth of Indonesia. Furniture industry is categorized as resources based industry, where the main raw material comes from local natural resources, in the form of wood and rattan, which is then combined with the typical craft of Indonesian culture.

The growth of the economy is quite exciting, especially in the sector of Industry and services, as well as the continuity of demand for timber forest products as raw materials for furniture industry, become a good opportunity for furniture industry. In addition, the furniture industry has been proven to contribute significantly to economic development through the provision of jobs, the absorption of raw materials of wood and the acceptance of foreign exchange. Moreover, forests also support the development of agriculture and plantations, as a mineral resource, a producer of mineral and gas as an energy source.

Currently, Perhutani manages the largest forest in the ASEAN region. This is a comparative advantage that is not owned by the other ASEAN countries. Perhutani has the largest forest area with the production of a typical type of teak.However, until now these advantages have not been used optimally so that the air does not add value. Perhu Perum forest area of 2.4 million hectares of farmers, but most are marketed in the form of raw wood and only 5\% is processed in Perhutani timber industry. The weakness of timber industry in Indonesia are (a) the technology used is still low, (b) innovation and its design is not update, (c) inadequate infrastructure so that raw material prices are too high (Ministry of Commerce, 2015). 
Establishment of strategic alliance or operational cooperation with strategic partner of Wood Industry in Perhutani around work areas need to improve competitiveness. Perhutani cooperating with strategic partners who have the characteristics of wood industrial products and markets, and/or have other similarities. Winata \& Devie (2013), prove the existence of a significant relationship between the strategic of alliance on competitive advantage. This means, strategic alliance able to increase the competitive advantage through access in specific markets, lowering financial risk, lower political risk, as well as to achieve and ensure competitive advantage.

Product innovation is the key component of a successful business operation, so that the company can have a competitive advantage and become a market leader (Henard \& Szymanski, 2001; Luke \& Ferrell, 2000). Additionally, Indriani (2005) also stated that the benefits of a product is one determinant of the success of new products. Meanwhile, Prasetya et al. (2007), states that environmental change is proven positive effect on strategic alliances and competitive advantage, while the product innovation proved no effect on strategic alliances and competitive advantage. Furthermore, Ibrahim (1998) revealed that in industry or processing activities, the main factor that should be considered in addition to product innovation is the market area. Market area is strategically timber will be able to minimize the costs to be incurred, such as the purchase cost of raw materials, transportation costs, labor, and so on. This means that most of the company's revenue just to cover the cost of transporting raw materials and products coming out of the company's services (Heizer \& Render, 2004). Buchari (2003) argues that the selection of the right market area to determine the success and failure of business in the future. One of the factors that should be considered in the selection of the market area is the proximity to the supplier or suppliers (Soehadi, 2003). Suppliers have an influence on the business in terms of speed of supply, product quality, shipping, and others so that the proximity to the source supplier market to be considered in the selection area. Based on these issues, this study aimed to examine the effect of strategic alliance to market area, product innovation and competitive advantage at timber industry of Perhutani.

This study has implications for thinking the need for a strategic alliance that both joint venture partners Timber Perhutani (1) forming a reconciliation of businesses Timber joining based on compatibility, mutual need and benefit, (2) how to maintain the perspective of business ag ar more focused and professional, (3) pooling of resources to what is already owned by the business partners so that the timber industry with a perfect alliance will impact the Company's success becomes superior.

\section{Literature Review}

Niemela et al., (1995) describes the interrelationships between enterprise customers, products, and local market strategies and firm size and geographical location. Company size is determined primarily by the local competition (industrial structure and technology) and timber resources, in turn, affects the company's pricing structure and selection of potential products. Product strategy, combined with the geographical demand factors, demand for the country of origin, and the elements of trade (access to distribution, trade policy, government, the exchange rate) would affect customer strategy and market area. Ultimately, these factors combine to affect the relative competitiveness of a company, region, or country. Toivonnen et al. (2005) describe the intangible product quality in three dimensions, behavior and image, service and environment, and reliability. The results also show that Nordic do not have a strong competitive position in Germany in terms of intangible product quality dimensions.

Furthermore, Utama (2003) states that one of the key factors to determine the success in this competition is through improving the company's competitive advantage. A possible approach that can be applied to companies in today's conditions is through strategic alliances. Alliance on one side acts cooperation but at the same time on the other side acts as a competition for the company. The role of competition is what companies need to realize by alliances with other companies because the role of competition from strategic alliances in principle will be an unintended competition for each company that performs strategic alliances. Meanwhile, Winata \& Devie (2013) proves the existence of a significant relationship between strategic alliances and competitive advantage, strategic alliances and corporate performance and competitive advantage and firm performance.

Prasetya et al. (2007) describes the theoretical and managerial implications regarding the steps to be taken by PT Pos Indonesia to improve the performance of companies through competitive advantage form product innovation, strategic alliancesand environmental changes. This means that the positive effect on the environmental changes and the competitive advantage of strategic alliances, strategic alliances positive effect on competitive advantage, competitive advantage and positive effect on the company's performance. However, product innovation proved not air influence on strategic alliances and competitive advantage.

Slightly different, Indriani (2005) states that the benefits of the product is one determinant of the success of new products. These advantages can be achieved with a strategic alliance to develop its resources. Next Odoom et al. 
(2010) also suggested that in order to compete must implement strategic alliances with timber companies both government and private. In another aspect, Iswara et al. (2007), Soehadi (2003), Bambang (2011) suggest that the market area affect the competitive advantage is a business strategy. Previous research has not considered the market area of strategic alliances to improve thecompany's competitive advantage, thus requiring further analysis.

\subsection{Hypotheses and Their Correspondence to Research Design}

\subsubsection{Strategic Alliances Affect the Market Area}

Cravens (2000) propose that competition market situation as a first step in designing new strategies or review existing strategies. Analysts this situation is carried out after a strategy is implied to determine the necessary changes in strategy. Assessment of the situation usually does the definition and market analysis and competitor analysis. Utomo (1994) states that expected from the strategic alliance is a product development and market development for a specific product or group, without having to remove entirely characteristic of the company before.

Elias (2013) states that the concept of a new market not only implies geographic location or where buyers and sellers meet to conduct commercial transactions. But it also extends the activity of making various varieties of products and creating new markets that did not exist before.

$\mathrm{H}_{1}$ Strategic Alliance has positive influence to market area

\subsubsection{Strategic Alliance and Product Inovation}

Alliances are needed to meet the needs of difficult due to some limitations. Alliance principles are cost sharing, risk as well as benefits and benefits. Alliance can be directed at the acquisition of knowledge and technological capabilities. Moreover, manufacturer and marketing alliance partners to support the development of the product. In the highly competitive business world, companies require an effort to deal with competitors who always compete in innovation, both in its technological aspectsas well as its product innovation (Kotabe, 1990). Li \& Chen (1999) mentions the benefits of the strategic alliance is a) pattern bear the costs of research and development together, b) acquire the knowledge and resources that may not be available internally if the company's stand-alone, c) allows expanding the product market. Indriani (2005) states the role of strategic alliances and product innovation has significant influence that the company is expected to always create continuous innovation and improvement in order to survive in a competitive situation.

$\mathrm{H}_{2}$ Strategic Alliance has positive influence to product inovation

\subsubsection{Market Area and Competitive Advantage}

The company's readiness to face competition is determined by market area. Market selection strategy area are brought closer to the target market aims to enable consumers to obtain the desired product. Bharadwaj et al. (1993) states that companies that emphasize attention to the market will lead to a strengthening competitive advantage. Lamb et al. (2001) states that choosing a good location is an important decision. In addition, government regulation, competition, and market area ofinfluence on business strategy (Bambang, 2011).

$\mathrm{H}_{3}$ Market area has positive influence to competitive advantage

\subsubsection{Strategic Alliance and Competitive Advantage}

Winata \& Devie (2013) found the influence of strategic alliances and competitive advantage. This result gives the sense that the strategic alliance exploited to gain competitive advantage in the marketplace. The strategic alliance is the answer for many companies that seek to gain competitive advantage (Hamel \& Prahalad, 1989). Furthermore, Ferdinand (2006) states that a very important competitive advantage for companies entering a competitive market, where short-term success even long-term will be determined by the ability of the company to build a strong basis for a sustainable advantage. For facing strong competitive pressures in the industry, emerging cooperative strategies in the form of strategic alliances. In many similar ways, strategic alliance with such license agreements, patent, trade mark or technical knowledge is granted to licensees over time and licensees will receive royalties and may be used to avoid tariffs or import quotas (Pearce \& Robinson, 1997).

$\mathrm{H}_{4}$ Strategic alliance has positive influence to competitive advantage.

\subsubsection{Product Inovation and Competitive Advantage}

Understanding of consumer profiles and behavior can provide valuable input to the company. Companies can target the target market for the products they develop, understand what consumers want and need, knowing the consumer's behavior in buying and choosing a product. The importance of strategic alliance role in the success of product innovation, pushing the company felt the need to develop frequency and intensity to take advantage of relationships 
with other companies, both concerning the fulfillment of the needs of technology, production and marketing.

Research Droge \& Vickrey (1994) found that the product be used as a source of competitive advantage. Companies are able to present the products quickly according to customer wishes will win the competition (Caldwell \& Ancona, 1990). Pearce \& Robinson (1997), Larsen \& Lewis (2007), \& Parkman \& Helder (2012) stated the importance of an effective and efficient can generate sustainable competitive adventage. Competitive adventage is a dynamic process, so it must be done continuously. Competitive adventage describe a company can do better than any other company in the same industry. The better intellectual capital and innovation will be the higher competitiveness (Jose, 2012). Anticipatory learning will generate competencies to propel numerous innovations that will create a competitive advantage (Garvin, 1991).

$\mathrm{H}_{5}$ Product inovation has positive influence on competitive advantage.

\subsubsection{Strategic Alliance and Competitive Advantage through Market Area}

Kotler \& Amstrong (2008) says that s ne of the keys to success is the market area. This decision relies heavily on the potential for economic growth and stability, competition, the political climate, and so on. Furthermore, Ibrahim (1998) revealed that in industry or processing activities, the main factor to be considered in the technical aspects of the production is the market area. Market is strategically able to reduce the costs to be incurred, such as the purchase cost of raw materials, transportation costs, labor, and so on.

Lupiyoadi \& Hamdani (2009) associate the location with which the company must perform an operation or activity. A da three types of interactions that affect the location, namely a) customers come to the company, this condition requires important market area. Companies should choose a place close to the con sumen so easy to reach, b) p reflected on services went to the consumer, in this context market area become not so important, but that should be considered is the delivery of services must remain qualified, c) reflected on services and consumers are not met directly, meaning service providers and consumers interact through certain means such as telephone, computer or mail so in this context market area become very important for the communication between the two sides carried out well.

Soehadi (2003) pointed out that partnership with suppliers positively influences company performance. The proximity of suppliers is crucial, getting away with the supplier, the higher cost of transportation and distribution of goods. The selling price of the goods will be greatly influenced by the level of the base material and basic material prices depend on the fees to be paid supplier to distribute the goods. Suppliers have an influence on the business in terms of speed of supply, product quality is maintained, shipping, and others so that the proximity to the source supplier market to be considered in the selection area

$\mathrm{H}_{6}$ Strategic Alliance has positive influence on competitive advantage through market area.

\subsubsection{Strategic Alliance and Competitive Advantage through Product Inovation}

Kotler \& Keller (2013) defines the product as something that can be offered to the market to satisfy a desire or need, including physical goods, services, experiences, events, people, places, properties, organizations, information and ideas. While Daryanto (2013) states the product as anything that can be offered to the market to get some attention, purchased, used or consumed and which can satisfy the desires or needs. Swastha \& Irawan (2003) state that the product is a complex nature, whether it can be touched or not touched, including packets, colors, prices, corporate prestige, service of employers and retailers, which buyers receive to satisfy wants and needs.

Furthermore Tjiptono (2000) defines the product as everything the manufacturer offers to be noticed, requested, searched, purchased, consumed market as fulfilling the needs of the market concerned. Droge \& Vickrey (1994) found that the product be used as a source of competitive advantage. Only companya with capability of providing a product according to the customers who are able to compete. That is the strategy of producing products that first appeared on the market is seen as the most effective approach to compete. To this end, most companies do product innovation as quickly as needed consumer, prior to issuing a competitor of similar products to the market.

$\mathrm{H}_{7}$ Strategic Alliance has positive influence on competitive advantage through product inovation.

\section{Method}

This study uses a quantitative approach with the step of 1) explore, formulate and determine the issues to be investigated, 2) design study model and parameter, 3) design instruments of data collection instruments, 4) collecting data, 5) processing and analyzing, 6) design a report (Bungin, 2010).

\subsection{Population and Sampling Procedures}

The population in this study were all timber companies who are partners and certified by Perhutani TLVS (Timber 
Legality Verification System) issued by the Ministry of Forestry. The sampling technique used was the census that is taking all members of the population, which is known as the saturation sampling (Sugiyono, 2011). The use of saturated sampling intended to obtain research data more precise and accurate. Wood company like Perhutani partners located in East Java and has a certificate TLVS (Timber Legality Verification System) issued by the Ministry of Forestry as many as 194 companies. Data collection is using closed questionnaire containing questions about the characteristics of respondents and is also associated with variables research, which includes a strategic alliance consisting of 7 questions, market area consisting of 7 questions, product innovation consists of seven questions and the competitive advantage consists of 6 questions. The questionnaire contains independent variables (perception of respondents regarding strategic alliances), the dependent variable (competitive advantage) and the mediating variables (market area and product innovation) using a Likert scale.

\subsection{Operational Variable}

The strategic alliance is a strategy that focuses on the agreement between the Perhutani with Perhutani partners who has obtained the Certificate of Timber Legality Verification System (TLVS) of the Ministry of forestry to share resources so as to bring benefits to both parties. Indicators of strategic alliances refer to Dussage \& Garrete (1998), namely a) Capacity of the combination of resources, is the ability to combine resources ad a between partners with Perhutani, b) Access to markets, an increase of the market carried out by partners with Perhutani, c) the continuation of the alliance, a continuation in establishing research agreement a between partners with Perhutani, d) Quality, an improved quality of service and product quality Perhutani with partners, e) ability competence, is an alliance built Perhutani with partners who are able to compete and competent with the product others in the wood industry, f) ability skills, the ability to improve the skills and knowledge resource for technology the bar u between partners with Perhutani, g) Coordination, is conducted jointly coordinate the ability to minimize the things that hinder the alliance.

Market area is the selection of market area not only geographical location but expanding activity to create new market by Perhutani with Perhutani partner to find optimal location (best economically). Indicators of market area refers to Iswara et al. (2007) namely geographically location, is the choice of location that easy to obtain timber, b) sosial culture, the labor supply, the marketing area, economic activity and political conditions, c) technology, the development of new technologies for processing product technological resources, energy, d) resource, is availability of timber and human resources, e) competency of Perhutani and their partners, f) transport cost, the transport costs derived from the transport timber, g) Uniformity of topography, climate and demographic objec related skills and the demand for production.

Product innovation developed by Perhutani and their partner is implementing by of a quality product and be accepted by the market, the brand/technical innovation, design, labeling/packaging, price, quality, service and warranties. Indicators of product innovation is refers to Rogers (2003), and Tjiptono (2000), namely a) creative, is the ability Perhutani with partners in creating new ideas pr oduk, b) inovation technically, is an innovation to development quality products, c) Changes design is the ability of Perhutani to produce the products that comply with the market timber industry, d) distribution channel, an attempt Perhutani in development right distribution, e) quality of, the ability of forestry in maintaining the quality of products in the timber industry, f) services and guarantees, is the ability of Perhutani in providing services and security for market timber industry, g) packaging, an ability of Perhutani in presenting packaging to attract buyers. Competitive advantage is the ability Perhutani to create value that is not owned and can not be imitated by competitors. Satyagraha (1994) uses indicators of competitive advantage that is unique, rare, not easily imitated, not easily replaced, and competitive price.

\subsection{Research Design}

After developed a theoretical model and establish the path diagram, the next is to translate path diagram into structural equation. In the path diagram, the causality relation comparable to the researcher can be shown by a line with one arrow (Sarwono, 2007). This study has an exogenous construct that strategic alliances and three endogenous constructs that market area, product innovation, and competitive advantage. Structural equation demonstrates causality between the various constructs in the model. Here is a translation path diagram into a structural equation.

$$
\begin{gathered}
M A=\beta 1 \mathrm{SA}+\mathrm{e} 1 \\
\mathrm{PI}=\beta_{2} \mathrm{SA}+\mathrm{e}_{2} \\
\mathrm{CA}=\beta_{3} \mathrm{SA}+\beta_{4} \mathrm{MA}+\beta_{5} \mathrm{PI}+\mathrm{e}_{3}
\end{gathered}
$$

Where:

$\mathrm{SA}=$ Strategic alliance 
MA $=$ Market Area

PI = Product inovation

$\mathrm{CA}=$ Competitive advantage

Furthermore, with SPSS were calculated coefficient (b1, b2, b3) between variables in the model. The values of coefficients that have an indirect relationship multiplied by a coefficient that has a direct relationship, and the results were compared with the coefficient values that have a direct relationship. If the result of multiplying the coefficient value is greater than the value of the coefficient that has a direct relationship, then the exogenous variables are variables mediation more effective in influencing the endogenous variables via other variables rather than directly. But if the opposite occurs, then the influence of exogenous variables on endogenous variables more effective directly, rather than through other variables. With the help of SPSS application can know the result of calculation (output) in the form of summary model, anova and coefficient.

Hypothesis is tested by the significant value of each path coefficient that describes the effect of partially exogenous variables on endogenous variables, namely the strategic alliance to competitive advantage, market area mediates the effect of the strategic alliance to competitive advantage, and product innovation mediate the effects of strategic alliances to competitive advantage

\section{Results}

\subsection{Validity Test}

Validity test can be done by using Pearson Product Moment correlation (Azwar, 2004). An item on the questionnaire is valid if the correlation coefficient is positive and greater than 0,30 or is greater than the value of $\mathrm{R}$ tables. Validity test results of the 7 indicators of strategic alliance have value $\mathrm{R}$ is bigger than $\mathrm{r}$ table $0138(\mathrm{~N}=194 ; \alpha=0,05)$, so that the entire statement is declared invalid. Validit test of market area has a value of $\mathrm{R}$ is larger than $\mathrm{R}$ table 0,138 $(\mathrm{N}=194 ; \alpha=0,05)$, so that the entire statement is declared invalid. The validity test of product innovation has a value greater than $\mathrm{R}$ table $0,138(\mathrm{~N}=194 ; \alpha=0,05)$, so that the entire statement is declared invalid. The Validity test of competitive advantage has a value greater than $\mathrm{R}$ table $0,138(\mathrm{~N}=194 ; \alpha=0,05)$, so that the entire statement is declared invalid.

Reliability is pointing right extent to which the measuring instrument is reliable or unreliable. Ghozali (2008) states that a construct or variable is said to be reliable if the Cronbach alpha value > critical value $(0,60)$. Based on the results of Cronbach alpha, strategic alliances have Cronbach alpha of 0.919, 0.934 market area, product innovation of 0.881 and 0.734 for competitive advantage is greater than the critical value $(0.60)$, meaning that all variables are reliable. This means that the measuring instrument used to measure the construct is relevant.

\subsection{Classic Assumption Test}

Test the residual normality of data using Kolmogorov-Smirnov Test, by comparing Asymptotic Significance with alpha $=0,05$. The data is said as normal if its Significance asymptotic value is $>0,05$. The test results show the value of the test statistic of 0,874 and the Significance Asymptotic 0,104 which means that the residual have normal distribution.

Multicollinearity can be seen by VIF with the tolerance values $\leq 0,10$ or VIF (Varinace Inflation Factor) $\geq$ VIF 10. The test results demonstrate the value of each of the strategic alliance (VIF $=2,455)$, Market Area $(\mathrm{VIF}=2,642)$ and Product innovation (VIF = 3.618), which means no multicollinearity. It is concluded that there is no relationship of the independent variables with other variables independent

\subsection{Structural Equation Models}

Test models is used to develop the model lines between the influence of exogenous and endogenous variables. The results of structural equation model test can be seen in the following table

Tabel 1. Structural Equations 1

\begin{tabular}{|c|c|c|c|c|c|c|}
\hline Model & $\begin{array}{l}\text { Unstandardized } \\
\text { coefficients } \\
\text { B } \\
\end{array}$ & $\begin{array}{l}\text { Standardized } \\
\text { coefficient } \\
\text { Std Error } \\
\end{array}$ & $\begin{array}{c}\mathrm{t} \\
\mathrm{Beta} \\
\end{array}$ & Sig & $\begin{array}{l}\text { Collinearity } \\
\text { statistics } \\
\text { Tolerance } \\
\end{array}$ & VIF \\
\hline (constant) & 7,844 & 1,330 & & , 000 & & \\
\hline Strategic alliance & ,664 &, 055 & 656 & ,000 & 1,000 & 1,000 \\
\hline
\end{tabular}

Dependent variable: market area 
Based on above calculations, the structural models is

$$
M A=0,656 \mathrm{AS}+0,569
$$

Tabel 2. Structural Equations 2

\begin{tabular}{|c|c|c|c|c|c|c|}
\hline Model & $\begin{array}{c}\text { Unstandardized } \\
\text { coefficients } \\
\text { B }\end{array}$ & $\begin{array}{c}\text { Standardized } \\
\text { coefficient } \\
\text { Std Error }\end{array}$ & $\begin{array}{c}\mathrm{t} \\
\text { Beta }\end{array}$ & Sig & $\begin{array}{l}\text { Collinearity } \\
\text { statistics } \\
\text { Tolerance }\end{array}$ & VIF \\
\hline (constant) & 7,752 & 0,997 & &, 000 & & \\
\hline Strategic alliance &, 678 &, 041 & ,764 &, 000 & 1,000 & 1,000 \\
\hline
\end{tabular}

Endogen variable: product innovation

Based on above calculations, the structural models is

$$
I P=0,764 \text { AS }+0,416
$$

\begin{tabular}{|c|c|c|c|c|c|c|}
\hline Model & $\begin{array}{c}\text { Unstandardized } \\
\text { coefficients } \\
\text { B } \\
\end{array}$ & $\begin{array}{c}\text { Standardized } \\
\text { coefficient } \\
\text { Std Error } \\
\end{array}$ & Beta & Sig & $\begin{array}{c}\text { Collinearity } \\
\text { statistics } \\
\text { Tolerance } \\
\end{array}$ & VIF \\
\hline (constant) & 0,534 &, 836 &, 639 & ,524 & & \\
\hline Strategic alliance &, 511 & 047 & ,577 & ,000 & ,407 & 2,455 \\
\hline Market area & , 137 &, 048 & , 157 &, 005 & ,378 & 2,642 \\
\hline Product inovation &, 225 &, 064 & ,226 & ,001 & ,276 & 3,618 \\
\hline
\end{tabular}

Tabel 3. Structural Equations 3

Endogen variable: competitive advantage

Based on above calculations, the structural models is

$$
C A=0,577 \mathrm{AS}+0,157 \mathrm{MA}+0,266 \mathrm{PI}+0,218
$$

Based on above equation, the structural models is

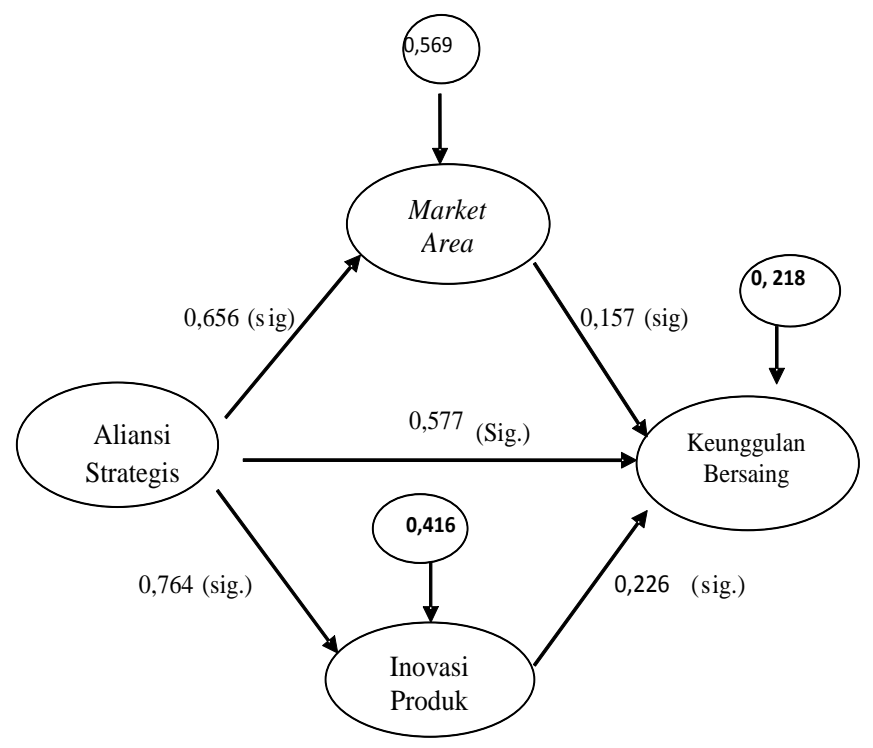

Figure 1. Path Diagram

\subsection{Goodness of Fit}

This goodness of fit is done by looking at the value of the coefficient of determination ( $\mathrm{R}$ square) and $\mathrm{F}$ significance test ( $F$ test). The value of $\mathrm{R}^{2}$ describes the ability of exogenous variables in the influence and significance of $\mathrm{F}$ endogenous variables explain the level of confidence that the model is appropriate or feasible (Ghozali, 2016). The 
test results show the value of the coefficient of determination of strategic alliances to market an area of 0.431 (less than 50\%), which means that strategic alliances are less good in explaining market area.

Next is the coefficient of determination $\left(\mathrm{R}^{2}\right)$ product innovation amounted to 0.584 , meaning that strategic alliances can explain the product innovation by 58, 4\%. The model is quite good because of above $50 \%$. As for the strategic alliance to market area and product innovation to the competitive advantage of yield determination coefficient of 0,782 or by $78,2 \%$ (greater than $50 \%$ ), which means this model is good enough.

\subsection{F-Test}

Model declared eligible if F count larger than F table and a significance level $(\alpha)>0,05$. Structural Model 1 (strategic alliance on market area) produce $F$ count 145,140 and a significance level $(\alpha)=0,00$ smaller than 0,05 , which means the structural model 1 declared eligible.

Structural Model 2 (a strategic alliance to product innovation) produce $F$ count 269.703 and significance level $(\alpha)=0$, 00 smaller than 0,05 , which means the structural model 2 declared eligible.

Structural Model 3 (strategic alliances, market area, product innovation to the competitive advantage) produce $\mathrm{F}$ count 226.619 and significance level $(\alpha)=0,00$ smaller than 0,05 , which means the structural model 3 declared eligible.

\subsection{Hypothesis Testing}

Path analysis is used to test the hypothesis with a view of the significant value of the each path coefficient. Test of path coefficient illustrate the effect of exogenous variables on endogenous variables, namely the strategic alliance to competitive advantage, market area mediating influence strategic alliance to competitive advantage, and product innovation mediate the effects of strategic alliances to competitive advantage. Results of t test can be seen in the following table

Table 4. The coefficient of $\beta$, t value and significance

\begin{tabular}{crr}
\hline Relationship & $\begin{array}{c}\text { Value of } \beta \\
\text { standardized }\end{array}$ & \multicolumn{1}{c}{$\mathrm{t}$ value } \\
\hline AS $\rightarrow$ MA & 0,656 &, 000 \\
AS $\rightarrow$ PI &, 764 &, 000 \\
MA $\rightarrow$ CA &, 157 &, 005 \\
AS $\rightarrow$ CA &, 577 &, 005 \\
PI $\rightarrow$ CA &, 226 &, 001 \\
\hline
\end{tabular}

The significant value of each variable in the above $<\alpha(0,05)$. We conclude that each of the independent variables affect the dependent variable. Meanwhile, to test the effect of indirect and direct effects can see the total effect is the sum of direct and indirect influence as shown in the following table.

Table 5. Direct and indirect effect of variables

\begin{tabular}{lccc}
\hline \multicolumn{1}{c}{ Variables } & Directly & Path Coefficient & Indirectly \\
\hline AS $\rightarrow$ MA & 0,656 & - & Total \\
AS $\rightarrow$ PI & 0,764 & - & 0,656 \\
MA $\rightarrow$ CA & 0,157 & - & 0,764 \\
AS $\rightarrow$ CA & 0,577 & - & 0,157 \\
PI $\rightarrow$ CA & 0,226 & - & 0,577 \\
AS $\rightarrow$ MA $\rightarrow$ CA & 0.577 & 0,102 & 0,226 \\
AS $\rightarrow$ PI $\rightarrow$ CA & 0,577 & 0,173 & 0,679 \\
\hline
\end{tabular}

Based on the table above can be explained that the indirect influence of strategic alliances to variable competitive 
advantage through the variable market area of 0,102 and the total effect of its 0,679 . Furthermore, the value of the indirect effect of the strategic alliance competitive advantage through product innovation 0,173 with a total value of 0,749 . Beta value or standardized coeficient of strategic alliance on competitive advantage 0,577.

\subsection{Mediation of Sobel Test}

Mediating variables measured by the $\mathrm{Z}$ test of the coefficient of $\beta$. If the value of $\mathrm{Z}$ count $>\mathrm{Z}$ tables and the significance $(\alpha)<5 \%$, it said that no mediation effect. Based on sobel test results, it is known that $\mathrm{n}$ use values and indirect effect of market area of 0,3308 and significance at 0,000, which means market area mediate the effect of a strategic alliance to competitive advantage, so that $\mathrm{H}_{6}$ that strategic alliance has positive influence on competitive advantage through market area is received.

The value of indirect effect market area 0,3308 and significance at 0,000 which means market area mediate the effects of strategic alliances to competitive advantage, so that $\mathrm{H}_{6}$ that strategic alliances affect the competitive advantage through market area is accepted. The value of indirect effect product innovation 0,3308 and significance at 0,000 which means product innovation mediate the effects of strategic alliances to competitive advantage, so that $\mathrm{H}_{7}$ that strategic alliances affect the competitive advantage through product innovation is accepted.

\section{Discussion}

\subsection{The Influence of Strategic Alliance on Market Area}

Based on the test results are known path model or standardized beta values coeficient strategic alliance to variable market area amounted to 0,656 and obtained significant $t$ test means the first hypothesis $\left(\mathrm{H}_{1}\right)$ which states that strategic alliance has influence on market area is accepted. Its means that strategic alliance of Perhutani through cooperation with the Timber Industry Partners are able to influence market area. Through strategic alliance, Perhutani able to combine the forces of partners Timber become a major force to improve the bargaining position in the global market. The timber industry market development through strategic alliances are expected to have characteristics as expected is able to dominate the global market. Wood Industry Potential partners who are members of the strategic alliance will be able to coordinate the procurement of raw materials, access to capital, marketing and process technology. Through this strategic alliance, the parties allied to benefit from such cooperation, even its position in the market is also getting stronger.

This result support Niemela et al., (1995) which describes the interrelationship between the enterprise customer, product and market strategy area and company size and geographic location. Company size is determined primarily by the local competition (industrial structure and technology) and timber resources, which in turn affects the company's pricing structure and selection of potential products. Product strategy combined with geographic demand factors, demand for the country of origin, and the elements of trade (access to distribution, trade policy, government, and exchange rate) would affect customer strategy and market area. Ultimately, these factors affect the relative competitiveness of companies, regions, or countries.

This finding is in accordance with Utomo (1994) states that w equivalent concrete strategic alliance is a product and market development for a specific product or group, without having to remove previously wholly characteristic. With strategic alliances, Manufacture of wood Perhutani will get the ease of entry into a new market, as according to Soares et al., (2007) with the communication technology is increasingly sophisticated, enhanced by the sophistication of information technology, computers and the ease of transportation, it will make entry into foreign markets much easier.

By entry to the foreign markets will increase the scale of business once Timber forestry product distribution becomes more widespread. The entry fee for the international market which have borne alone, then with the strategic alliance will lower the cost. The next advantage to be gained by making strategic alliances are sharing the risk, which is one reason companies do strategic alliances is shared business risk in the face of uncertainty in entering the open market.

\subsection{Strategic Alliance and Their Influence on Product Inovation}

The value of standardized coeficient of strategic alliance on product inovation of 0,764 with significance on t-test means theat the second hypothesis $\left(\mathrm{H}_{2}\right)$ which states that a strategic alliance striving towards product innovation accepted. It is showed that strategic alliances are built Perhutani through cooperation with Industry Partners Wood is able to stimulate and increase product innovation. Market demands require that the raw material of wood products should be clear rules of origin her and must come from sustainably managed forest.

Strategic alliance ensures speed and flexibility for easier adjustment to new technological changes. Strategic alliance can be directed to update their knowledge and capabilities of technology, manufacturing and marketing of the alliance partners will then be useful in supporting product innovation. In a highly competitive business, companies require an 
effort to deal with competitors that innovative, both concerning the technology used for the production processes and innovations on the product itself.

The results of this study also supports the Indriani (2005) that the role of strategic alliances to product innovation is significant influence so that the company always creates innovation and continuous improvement in order to survive in a competitive situation. Generally, fast-growing company that relies heavily on strategic alliances to expand raw material resources, technical and operational. With the Company's strategic alliance is expected to save time and increase productivity, because it does not have to develop all the production process from the beginning, and can concentrate on innovation and core business (Perry, 2000).

\subsection{Market Area and the Influence on Competitive Advantage}

Based on the results of the model test track, known or standardized beta values coeficient variable to variable market area competitive advantage by 0,157 and the value of the significant known test means a third hypothesis $\left(\mathrm{H}_{3}\right)$ which states market area striving towards competitive advantage accepted. It is means Perhutani strategy built through the development of market area will be able to increase competitive advantage.

The results support the research Odoom et al. (2010) which examined the Company's timber sector in Ghana in implementing its export strategy with the support of local governments in the form of easiness process of implementation of export commodities produced timber, so that the company can compete well in the international market. This shows that through a special access to get the ease of regulation, transport and other infrastructure, $p$ ompany will seek to develop the market area with the hope of increasing competitive advantage. Selection of the market area will affect the risks and benefits for the company as a whole, considering the location greatly affects the fixed costs and variable costs, both in the medium and long term.

\subsection{Strategic Alliance and the Influence on Competitive Advantage}

Based on path analisys it is know that standardized values coeficient strategic alliance to variable competitive advantage amounting to 0,577 dan based on $t$ test is significance means that the fourth hypothesis $\left(\mathrm{H}_{4}\right)$ which states the strategic alliance striving towards competitive advantage be accepted. It showed that strategic alliances are built Perhutani through cooperation with Partner Timber able to increase competitive advantage.

These results reinforce Winata and Devie (2013) who proved a significant correlation between strategic alliances and competitive advantage, strategic alliances and corporate performance and competitive advantage and firm performance. While Nurrochmat \& Tiryana (2000) analyzed the domestic and export marketing development of Indonesian plywood products, show the results also support the results of this research is in bubarkannya association of timber resulted in the marketing situation of Indonesian plywood increasingly lethargic and depressed. The volume of plywood exports dropped dramatically. Nurrochmat \& Tiryana (2000) suggested the need to give a chance back for Alian the strategic with voluntary membership. Strategic alliance will encourage Perhutani positioned to establish a subsidiary can be realized with the capacity, quality and source of raw material that allows to produce high value products (Hamel \& Prahalad, 1989).

Perhutani is currently expected to immediately clean with cooperating partners such as financiers, designer furniture, from artisans to associations such as the Association of Indonesian Furniture Industry \& Handicraft where patterns can be applied is with the cooperation of raw materials supplied from Perhutani, design and creative processed partners, then partner find a market with the brand carries the name of Indonesia.

Strategic alliance is measured by 7 indicators of a strategic alliance that was built to improve the relations sustainable and cooperation to improve the competitiveness of the partner company, improving the quality of service the company to face competition mainly wood industry, increasing the company's ability to compete and compete enhance the ability to combine existing resources, improve coordination and joint activities undertaken to minimize the things that hinder the alliance, increasing the ability to access a wider market for the company, and improve the ability of technology to improve the skill and resources of the company,it turns out almost all cooperation partners stated that the strategic alliance that was built to enhance the company's ability to compete and compete. Besides that, a strategic alliance to improve access to a wider market. Thus, the strategic alliance is to increase the value added to take advantage of the company and compensate for the weaknesses with the advantages of a partner can be reached. This means that each party in alliance with each other to contribute in the development of one or more of the key strategies in the field of business cooperation.

The results also support Hidayat (2013) found that the strategic alliance has a positive effect on the competitive advantage of Small and Medium Enterprises. Meanwhile, Prasetya et al, (2007) stated that the more precise strategic alliance conducted a positive influence on competitive advantage. Bleeke and Ernst (1991) said that the formation of 
strategic alliances and cooperation are especially motivated to get a competitive advantage in the marketplace. The strategic alliance also described as a key to competitive success (Ohmae, 1986; Saxenian, 1994).

In addition, a strategic alliance takes advantage of Perhutani in terms of raw material teak logs and offset the weakness of Perhutani product innovation and market share based on advantages of the timber industry partners. Besides that, a strategic alliance intended to Perhutani timber industry can gain strength to share important resources both in terms of production technology and market access.

\subsection{Product Inovation and the Influence on Competitive Advantage}

Based on the results of the model test track, known or standardized beta values coeficient product innovation to variable Competitive advantage amounting to 0.226 and the $\mathrm{t}$ test known significant mean fifth hypothesis $\left(\mathrm{H}_{5}\right)$, which states product innovation striving towards Competitive advantage accepted.

The results support the Supranoto (2009) that the product innovation positive effect on Competitive advantage. Long products continuously redesigned, and new products unceasingly developed (Handoko, 2000: 32).

Through strategic alliances, Manufacture of wood Perhutani providing quality wood so that partners strategic alliance to develop and create a product that has a sale value and high competitiveness quickly and accurately, so that it can enter the market faster than competitors and will further enhance the competitive advantage of both parties, For that in the process of product innovation, Perhutani timber industry should be able to utilize its resources optimally by conducting product innovation to maintain the viability of the company. Even Pearce and Robinson (1997: 154), states that effective and efficient innovation will be able to generate a sustainable advantage.

Product innovation applied by Perhutani in terms of product quality, product price, and the guarantee of the product received responses agree and strongly agree $97.5 \%$ of respondents. This indicates that the entire forestry industry partners agree their product innovation.

Product innovation is becoming increasingly important and recognized as a strategy in response to an increasingly competitive business competition and has a great influence on the performance and competitiveness of the company. Through product innovation, decision makers can make decisions to overcome business problems and challenges that arise and provide a solid foundation to maintain the viability and success in the long term (Satyagraha, 1994). Innovation can also be used as one of the strategies to achieve competitive advantage. The main purpose of the product innovation is to meet the market demand so that product innovation is one that can be used as a strategy to achieve competitive advantage for the company (Han, 1998).

\subsection{Strategic Alliance and the Influence on Competitive Advantage through Market Area}

Based on the results of the test track, indicates that the value of the coefficient $j$ groove by multiplying the value of $\beta 1-\beta 4$ of 0,102 with a total value of 0,679 . With known beta value of strategic alliances to variable competitive advantage $(0,577)$, it was explained that the variable market area is the variable that is able to mediate partial strategic alliance to variable competitive advantage. Because the value of the total effect is greater than the value of its direct effect $(0,679>0,577)$. It is also on show with the test results Sobel test where $t$ is greater than $t$ table with a significance level of 0.05 is equal to 1.65 so that it can be concluded that the coefficient of 0.3308 and significant mediation at 0,000 , which means there is influence of mediating variables means market area become mediating variables to influence strategic alliance to competitive advantage. With the value of a positive correlation track, meaning the right strategic alliances made will enhance the development of the market area, the increasing development of market area can increase the competitive advantage of wood industry Perhutani joint alliance partners.

The research result is strengthening Soehadi (2003) that a partnership with suppliers to positively influence the performance of the company. The proximity of a business with its suppliers will determine the cost of transportation and distribution of goods. Moreover, suppliers have influence on the speed of supply, product quality is maintained, the cost of shipping.

During this comparative advantage in the form of potential Perhutani teak distinctive types untapped optimum added value. $\mathrm{H}$ acyl timber industrial production largely export-oriented, but the export conducted by Perhutani timber industry largely through an intermediary (buyer), so Perhutani do not have complete knowledge about the consumer abroad. This condition causes Perhutani timber industry is highly dependent on foreign buyers and value added enjoyed by people in foreign countries. Price and design of the wood industry is highly dependent on outsiders. Through the implementation of strategic alliances like this can be fixed and the destination competitive advantage can be obtained.

From the context of industry strategic alliance, the interaction between users and providers of various parties can take 
intensive and relatively continuous, due to various obstacles can be minimized. Strategic alliances competitive timber industry needs to be developed through other forms of activities that allow easy access to the physical infrastructure, technology, market information, sources of raw materials, services, special services, marketing and other related industries. Development of timber industry and the timber industry strategic alliance approach is an effort to address problems through an integrated approach, realistic and effective. Furthermore, the marketing system needs to be improved further improve the ability of marketing in particular so as to carry out a better marketing strategy through market research, promotion of the timber industry both locally or to foreign countries, which is accompanied by an increase in quality of production. With increasing market area of at least 194 area, then the appropriate strategy for the marketing of forestry and timber industry will partner can increase the competitive advantage of Perhutani.

\subsection{Strategic Alliance and the Influence on Competitive Advantage through Product Inovation}

Based on the test results, indicating that the path coefficient value of the multiplication result the value of $\beta 2$ to $\beta 5$ of 0,173 with a total value of 0,749 . By knowing the beta value of strategic alliances to competitive advantage (0.577) it was explained that the product innovation is capable of variable me partial mediation strategic alliance to variable competitive advantage, because the total effect is greater than the direct effect $(0,749>0,577)$. It is also on show with test results showing the Sobel Test mediation coefficient of 0.2024 and significant at 0,000 , which means there is influence of mediating variables. It means that product innovation be mediating variables to influence strategic alliance to competitive advantage.

With a positive correlation value lines, indicating that the product innovation programmed, quality and guarantees will be able to increase the competitive advantage of Perhutani with its alliance partners. The results of this study is in line with Bharadwaj et al (1993) that the company's ability to continue to innovate on the product - the product will keep the product remains in accordance with the wishes and needs of customers.

Besides that, according to Kotler (2002) that the purpose of the company doing product innovation is to maintain viability for existing products vulnerable to changes in the needs and tastes of consumers, technology, product life cycles are shorter, and increased domestic and foreign competition. This is in line with Indriani (2005) which states that the role of strategic alliances and product innovation have significant influence that the company is expected to always create innovations for products produced by the company and make continuous improvements in order to survive.

Based on the test results the path above, it can be seen that the accuracy of the strategic alliance Perhutani partner and the timber industry, in implementing the strategy to make its products as a product, which first appeared on the market is the most effective strategy to compete with competitors in the same industry that is wood, so the company should strive to make product innovation rapidly, presenting products that consumers need. Product innovation characterized by uniqueness of the product, the product is rare, not easily imitated, not easily replaced, and competitive prices, will become part of the uniqueness of the company's products in other words, product innovation means integrating the value of art to the taste of the customer.

Perhutani need to revitalize existing timber industry, taking into account the overall condition of a lumber mill owned by Perhutani. For SOEs, Perhutani has many advantages that can be a competitive advantage as source of raw materials. In-depth studies related to the product innovation needs to be done carefully, because it is associated with the ability to compete with the private sector in terms of finished product and the ability to penetrate the market. Furthermore, in carrying out the revitalization of the wood industry, Perhutani should put forward its orientation as an agent of development, in the sense Perhutani should be an industry that supports the private timber industry (Droge \& Vickrey, 1994, Caldwell \& Ancona, 1990) states that the strategy for making the product as a product, which first appeared on the market is seen as the most effective approach to compete with competitors, both at home and abroad.

During this time, the cooperation takes place through sub-contract production of semi-finished products or components to meet demand for buyers to companies on a smaller scale. This allows the growth of specialty products. Specialties products can be derived from the wood raw material (wood type), design and quality, or the constituent raw material (solid wood, plywood, MDF, particle board). While functional, finished products produced wood industries ranging from floo ring, furniture and so on. If p roduction Perhutani teak total numbering $403432 \mathrm{~m} 3$ of logs cooperated with 194 teak wood industry partners with a capacity above $2000 \mathrm{~m} 3$ per year it will produce a minimum of 194 types of product innovation required by the market. Through a strategic alliance, the two companies will try to develop, engineer, and market a new product line based timber for the wood industry. $\mathrm{M}$ anfaat obtained by diversification without having to through mergers or bear the risk of product innovation new individually (Hill and Jones, 1992).

\section{Conclusion}

Based on the results of hypothesis testing and the analysis of strategic alliances, market area and product innovation 
against competitive advantage, it is known that building a competitive advantage in the timber industry forestry can be achieved through the establishment of strategic alliances right, based on the exchange of raw material resources, technology or resources marketing. Strategic alliances are used to strengthen the position of the timber industry in the face of competition forestry business. The more precise the model selection strategic alliance Perhutani timber industry will be able to build competitive advantage of her. The development model of strategic alliances Perhutani timber industry that needs to be developed is to increase the competitive advantage has the form of an alliance focused on cooperation in provision of raw materials, interest in improving the skills of cooperation and the application of the production process technology.

The results of field observations indicate that the relationship between the timber industry with raw material suppliers, have a strong relationship interactions. These linkages should have mutual intensity needs to be done. Of the three variables above that strategic alliances, market area and product innovation both test and partial test models have a direct influence on the competitive advantage, which led to the development of the theory as follows

\subsection{Strategic Alliance}

Built strategic alliances with industrial partners Perhutani known that teak wood originating from the Perhutani is a raw material vital to the survival of the timber industry, especially furniture and woodworking industry, where teak has been a comparative advantage for furniture and woodworking industry. Therefore the central government through the Perhutani responsible for products to national timber industry to remain competitive in the international competition. As the owner of the forest area, Perhutani has the authority in the allocation of wood raw material in the industry, which is now largely dependent on market mechanisms, however Perhutani marketing policy can affect this allocation.Given that the authority owned Perhutani has contributed very important for the survival of the timber industry in Indonesia.

The Challenge of current and future business is how much tolerance can be given to the parties allied to control the business together. Cooperation through a strategic alliance will lead the industry to collective efficiency so that any company that has the advantage would offer the goods/services to others. Perhutani as a raw materials supplier must provide the supply of various products (materials) required for the wood industry partners as a maker of finished goods. Therefore, the competitiveness of this strategic alliance also depends on how the cooperation of these companies provide the materials needed to price, quality, and time accordingly. Hence the alliance process often hampered because of the cultural differences between companies in alliance.

The strategic alliance between General Industrial Wood with Perhutani can be made according to two patterns, namely partner of Timber directly entered into an agreement directly with Perhutani and ASMINDO as channeling agent and through ASMINDO, partners Timber Industry joined forces to conduct a cooperation agreement, s ehingga agreement made between ASMINDO (representing members) with Perhutani. In this kind of cooperation, the provision of credit to the Wood Industry Partners done ASMINDO position as the Executing Agent. Production process problems are the responsibility of ASMINDO.

Furthermore, Perhutani with the timber industry partners need to equalize the inter-company culture, so that strategic alliances successful. Each party should have a strong culture, so they can build a corporate image to one another and must co-exist. This relates to the core competence, which the company directs its control to the things that are a competitive advantage, then the inter-company culture timber industry must come together.

\subsection{Market Area}

Based on the test results and test Sobel test track, variable market area known to mediate a strategic alliance to variable competitive advantage. Market area with regard to the marketing area, economic activity, technology, energy resources, and ease of transport facilities in support of the company, the climate, and demographics. Election strategy market area must be adjacent to the target market, it is intended to enable customers to obtain the desired product. It shows that in determining the need for analysis of the market area of the market situation, where the market situation analysis is the first step in designing new strategies or review existing strategies. The information for the public about the condition of each main market of Indonesian timber industry into a major importer countries such as China, Germany, Japan, the EU, India, and Middle Eastern countries. For each of these markets, sought after area and forest resources, population, income levels, the amount of production and consumption of a variety of wood products as the basis for assessment of the potential market.

\subsection{Product Inovation}

Based on the results of the model test track that product innovation mediate a strategic alliance to variable competitive advantage. While the theoretical findings of this study based on the responses of respondents product innovation which must have a unique product, the product is rare, not easily imitated, not easily replaced, and competitive price. The 
uniqueness of the product means integrating the value of art to the taste of the customer. Competitive prices is the company's ability to adjust product prices with common prices in the market. Not easy to find meaningful existence is rare in the competition which is currently done. Not easily imitated means can be emulated not perfect. Hard to replace means not having a replacement of the same.

Product innovation to be developed by Perhutani with the timber industry partners must have advantages compared to other products. To be able to create new products that have a competitive advantage, Perhutani with the timber industry partners must be able to do and develop its resources.

To develop the timber industry, should refer to the product standards as a condition that must be met in the production process so that it can be accepted certain markets, must be obtained by Perhutani timber industry. In principle, employers timber industry and the exporters can meet the requirements of the product, environmental and product safety established by a country, but the problem lies in the cost of the maintenance process and the fulfillment of these requirements is charged directly to the employer, which in turn have an impact on the increase in production costs and a reduction in value profit margins. With the strategic alliance, then such obstacles can be resolved easily and does not burden the cost of the company as on the responsibility of both.

\subsection{Competitive Advantage}

In between the lines studied equation model is a model pathway product innovation that mediate partial strategic alliance to competitive advantage is the most powerful lines. This means that the ability of Perhutani with partners to deliver more value to its products than its competitors and that value does bring benefits to customers, will increase the competitive advantage of Perhutani compared to competitors in the same industry. The accuracy of the model selection and the selection of strategic partner will be invited berliansi can improve competitive advantage, wherein the applied Perhutani alliance partner and is an ongoing strategic alliance. It also shows that the wood raw material sourced from teak forests managed by Perhutani is one of the factors that determine the comparative advantages of the timber industry and make a major contribution in determining the cost of production.

The support of the central government (Ministry of Forestry, the Ministry of Industry and Trade Ministry) and local governments (provincial and district) is expected to create a competitive advantage of industry entrepreneurs timber and timber products exporters. The support of goverments are expected to include (I) a consistent policy to support the procurement of raw materials that are legal and sustainable, (ii) tax incentives and fiscal measures to facilitate the restructuring (independence) timber industry, (iii) the import and export regulations are consistent, transparent and predictable, (iv ) rationalization of import tariffs for raw materials and production machinery, (v) improved transport infrastructure, communications, dams information, and (vi) strengthening the institutional infrastructure support for industry (associations, institutes R \& D, education and training, the office of export promotion, standardization, certification and labeling, verification bodies for legality (legality), and (vii) the government's role in supporting the export marketing should be more flexible because the private sector can not be forced to export but subject to on the condition of the factors of production in domestic and export markets faced.

\section{References}

Ancona, D. G., \& D.F. Caldwell. (1990). Beyond boundary spanning: Managing external dependence in product development teams. Journal of High Technology Management Research.

Bharadwaj, S.G., Varadarajan, P.R., \& Fahy. J. (1993). Sustainable competitive advantage in service industries: a conceptual model \& research propositions. Journal of Marketing, 57(4).

Bleeke. J., \& D. Ernst. (1991). The way to win in cross-border alliances. Harvard Business Review.

Buchari, A. (2003). Manajemen Pemasaran dan Pemasaran Jasa. Penerbit Alfabeta Bandung.

Bungin, B.H.M. (2010). Penelitian Kualitatif. Penerbit Kencana Prenada Media Grup. Jakarta.

Caldwell, D., \& D.G. Ancona. (1990). Improving the Performance of New Product Teams. Research.

Chandra, G. (2004). Pemasaran Global: Internasional dan Internetisasi. Penerbit Andi. Yogyakarta.

Daryanto. (2013). Sari Kuliah Manajemen Pemasaran. Cetakan II. Sarana Tutorial Nurani Sejahtera. Bandung.

Droge, C., \& S. Vickrey. (1994). Source and Outcomes of Competitive Advantage: An Explanory Study in the Furniture Industry. Decision Sciences.

Ferdinand, A. (2006). Metode Penelitian Manajemen: Pedoman Penelitian untuk Skripsi. Tesis dan Disertasi Ilmu Manajemen. Badan Penerbit Universitas Diponegoro. Semarang. 
Garvin, D.A. (1991). Building a Learning Organization. Havard Business Review.

Ghozali, I. (2008). Model Persamaan Struktur Konsep dan Aplikasi Dengan Program Amos 16. BP-UNDIP. Semarang. . (2016). Aplikasi Analisis Multivariat dengan program IBM SPSS 23. BP-UNDIP. Semarang.

Hamel, G.Y. Doz., \& C.K. Prahalad. (1989). Collaborate with Your Competitor and Win. Harvard Business Review, $67(1)$.

Han, K. S. (1998). Costumer-led and Market Oriented Let's Not Conjuse The Two. Strategy Management Journal.

Handoko. (2000). Dasar-Dasar Manajemen Produksi dan Operasi. Edisi 1 BPFE-Yogyakarta. Yogyakarta.

Heizer, J., \& Render, B. (2004). Manajemen Operasi. Buku 2. Edisi 9. (Diterjemahkan oleh: Sungkono. C.). Salemba Empat. Jakarta.

Henard, H.D. \& D.M. Szymanski. (2001, August). Why Some New Products Are More Successful Than Others. Journal of Marketing Research, 38(3).

Hidayat, A. (2013, April). Aliansi Strategis Dalam Membangun Keunggulan Kompetitif Usaha Kecil Menengah Di Indonesia. Widyariset, 16(1).

Ibrahim, H.M.Y. (1998). Studi Kelayakan Bisnis. Rineka Cipta. Jakarta.

Indriani, F. (2005), Aliansi Strategis Dan Pengembangan Produk. Jurnal Studi Manajemen \& Organisasi. UNDIP, 2(1).

Iswara, A.W. HV. Evania, \& I Wayan S. Wicaksana. (2007). Pemilihan Lokasi Usaha dengan Pendekatan Metode Tree Decision. $\quad$ Retrieved 9 Juli $2017, \quad$ from http://iwayan.staff.gunadarma.ac.id/Publications/files/738/2007_Pesat_LokasiTreeDec_IWS.pdf. Diakses

Jose, S.G., \& E.G. Gonzales. (2012). The Effect of Intellectual capital and innovation on Competitiveness: An analisys of the restaurant industry in Guadalajara. Meksixo. ACR, 20(3).

Kotabe, M. (1990). Corporate Product Policy and Innovative Behavior of European and Japanese Multinations: An Empirical Investigation. Journal of Marketing, 54.

Kotler, P. (2002). Marketing Management. Millenium Edition North Western University. Prentice Hall Inc. New Jersey.

. (2013). Manajemen Pemasaran. Jilid 1. Edisi 13. Erlangga. Jakarta.

Kotler, P., \& G. Armstrong. (2008). Prinsip-Prinsip Pemasaran edisi 12 jilid 1. Erlangga. Jakarta.

Kotler, P., \& K.L. Keller. (2013). Manajemen Pemasaran. Alih Bahasa: Benyamin Molan. Edisi Ketigabelas. Jilid 1 \& 2. Cetakan Keempat. PT. Indeks. Jakarta.

Lamb, C.W., J.F. Hair, \& C. Mc Daniel. (2001), Pemasaran. Alih bahasa David Octavaria. Salemba Empat. Jakarta.

Larsen, P., \& A. Lewis. (2007). How Award Winning SMEs the Barriers to Innovation. Journal Creativity and Innovation Management, 141-151.

Lupiyoadi, R., \& A. Hamdani. (2009). Manajemen Pemasaran Jasa. Edisi kedua. Salemba Empat. Jakarta.

Niemela, J.S., \& P.M. Smith. (1995). a marketing strategy comparison: Finland. Western United States and British Columbia. Forest Products Journal.

Nurrochmat, D.R., \& Tatang Tiryana. (2000). Analisa keseimbangan pasar dan reposisi strategi pemasaran kayu lapis. Jurnal Manajemen Hutan Tropika, 6(2).

Odoom, D.M.S., \& P. R. Vlosky. (2010), Strategic positioning analysis of Ghana's national wood export sector. African Journal of Business Management, 4(6).

Ohmae, K. (1986). Becoming a Triad Power: The New Global Corporation. International Marketing Review.

Parkman, I. D., Samuel, S. H., \& Helder, S. (2012). Creative industries: Aligning Entrepreneurial Orientation and Innovation Capacity. Journal of Research in Marketing and Entrepreneurship.

Pearce, \& Robinson. (1997). Manajemen Strategis. Terjemahan. Penerbit Binarupa Aksara. Jakarta.

Perry, M. (2000). Mengembangkan Usaha Kecil: Dengan Memanfaatkan Berbagai Bentuk Jaringan Kerja Ekonomi. Terjemahan Satrio TB. Terjemahan dari: Small Firm and Networks Economies. Raja Grafindo Persada Jakarta. 
Prasetya, G.L.H. E., \& Rahardja. R. Hidayati. (2007). Membangun Keunggulan Kompetitif Melalui Aliansi Stratejik Untuk Meningkatkan Kinerja Perusahaan (Studi Kasus Pada PT. Pos Indonesia Wilayah VI Jateng Dan DIY). Jurnal Studi Manajemen \& Organisasi, 4(2).

Rogers, E.M. (2003). Diffusion of Innovation (5th ed.). Free Press. New York.

Sarwono. J. (2007), Analisis Jalur untuk Riset Bisnis dengan SPSS. Andi: Yogyakarta.

Satyagraha. H. (1994). Keunggulan Bersaing dan Aliansi Strategis: Redefinisi SWOT. Usahawan. No.4.Th.XXIII.

Saxenian. A. (1994), Regional Advantage. Culture and Competition in Silicon Valley \& Route 128. Cambridge. MA: Harvard Business Press.

Soares. S., Amaral. J.S, Oliveira. M.B.P.P., \& Mafra. I. (2007). A SYBR Green real-time PCR assay to detect and quantify pork meat in processed poultry meat products. Meat Science, 94.

Soehadi W. A. (2003). The Relationship between Supplier Partnerships. Environmental Variables and Firms Performance in Retail Industry. Jurnal Ekonomi Dan Bisnis, IX(2). September 2003 Windows of Oppurtunity: Refleksi Sikap Opurtunistik Manajemen.

Sugiyono. (2011). Statistik Untuk Penelitian. Cetakan kesebelas. CV. Alfabeta. Bandung.

Supranoto. M. (2009), Strategi Menciptakan Keunggulan Bersaing Produk Melalui Orientasi Pasar. Inovasi. Dan Orientasi Ke Wirausahaan Dalam Rangka Meningkatkan Kinerja Pemasaran. Jurnal Bisnis.

Swastha, B., \& Irawan. (2003), Manajemen Pemasaran Modern. Edisi ke-2. Liberty. Yogyakarta.

Tjiptono, F. (2000), Manajemen Jasa. Edisi kedua. Penerbit Andi. Yogyakarta.

Utama. A. (2003), Upaya Meningkatkan Keunggulan Kompetitif Perusahaan Dalam Era Persaingan Global Melalui Aliansi Strategis. Kajian Bisnis No. 30 September - Desember 2003. 57-73.

Utomo. H. (1994), Strategi Aliansi dan Persaingan Global. Usahawan, 23(11).

Winata, J.D., \& Devie. (2013). Analisa Pengaruh Aliansi Stratejik Terhadap Keunggulan Bersaing dan Kinerja Perusahaan. Business Accounting Review.UK. Petra, 1.

Zuhri, S. (2013). Perhutani Fokus Garap Produk Lantai Kayu [Online News]. Retrieved from http://industri.bisnis.com/read/20131009/99/168088/javascript 